\title{
GAETANO SCIASCIA
}

\author{
Alexandre Augusto de Castro Corrêa \\ Professor Catedrático da Faculdade de Direito da \\ Universidade de São Paulo
}

O professor Gaetano Sciascia, falecido em Roma, em 1994, aos 80 anos de idade, foi um talento versátil: egrégio professor de Direito Romano ocupou também a secretaria da Corte Constitucional Italiana, tendo ali se aposentado. Distinguiu-se ainda como literato, deixando apreciável bagagem poética.

Vindo, ainda jovem, para São Paulo em 1947, colaborou durante quase dez anos com o professor Alexandre Corrêa na cátedra de Direito Romano da Faculdade de Direito da Universidade de São Paulo, tendo ensinado ainda a mesma disciplina na PUC de São Paulo e na de Campinas. Sua produção jurídica mais importante em português foi o Manual de Direito Romano, publicado em 1949 ( $1^{\mathrm{a}}$ ed.) em colaboração com o professor Alexandre Corrêa. Esse Manual, único na época, circulou durante vários anos por todas as faculdades de Direito do Brasil. Graças, por outro lado, à convivência com o professor Gaetano Sciascia foi que o autor destas linhas afrontou com êxito a tradução portuguesa dos Comentários de Gaio, trabalho que the custou quase dois anos. Foram também de inestimável valor as sugestões do mestre italiano ao abaixo assinado quando da elaboração de sua tese de livre-docência sobre $O$ estoicismo em Direito Romano.

Como consultor jurídico, o professor Gaetano Sciascia prestou valiosos serviços ao consulado italiano em São Paulo. Aqui durante sua longa permanência granjeou prestígio e grande número de amigos. Regressando à pátria Gaetano Sciascia foi chamado à Corte Constitucional, onde se aposentou depois de colaboração profícua junto àquele órgão. Aposentado, dedicou-se à literatura, tendo publicado vários trabalhos tais como Bianco e Nero Mille anni di Mito, Favola, Poesia 1 v., Roma; Poesie Giocose Latine Rinnovellate - 1 v., Roma; Il Decamerone in Versi e Rime 1 v., Roma; Fantacrociera Spaziale; Prose e rime extravaganti; La collana di Matidia Racconti archeologici (Roma e Castelli Romani); Parlami di amore - 50 sonetti di Gaetano Sciascia.

Comecemos este pequeno apanhado analisando brevemente os trabalhos literários do autor. A epopéia dos astronautas inspirou-lhe a Fantacrociera spaziale, poema elegantemente rimado e dividido em nove cantos, dedicados depois 
dos dois primeiros, aos planetas de nossa galáxia; trata-se de fantasia motivada pelo grande acontecimento de nosso século. Essa composição é de 1981.

Gaetano Sciascia preenchia também suas horas de lazer praticando o xadrez de que era brilhante amador; e seu gosto pelo nobre jogo levou-o a compor Bianco e Nero Mille anni di Mito, Favola, Poesia. Do xadrez já se disse que é frívolo demais para ser uma ciência e difícil demais para ser um jogo... Mas os amigos desse passatempo são inúmeros em toda parte e a eles principalmente se destina o livro de Sciascia, escrito em prosa e verso. Na "Premessa" encontramos esta apreciação final bastante acertada: "Divertimento nella sua essenza, arte $e$ tecnica nella forma, addirittura scienza nell'impalcatura normativa, il gioco degli scacchi è sempre motivo di fiaba e di mistero"

Mas a obra mais expressiva do talento literário de Gaetano Sciascia talvez seja Il Decamerone in versi e rime; o autor não era poeta no sentido estrito do termo, pois sua vocação era essencialmente jurídica; mas versificava com graça e elegância de modo a ler-se com muito agrado o resumo em poesia da grande obra de Boccaccio. No verso da capa do volume encontramos apreciação bastante justa: "Volgarizzando così il Decamerone del Boccaccio, l'autore há intesso renderlo accessibile al lettore moderno, non soltanto aggiornandone la lingua senza tradirne il contenuto, ma altresì cogliendo in esso gli aspetti più attuali e piccanti" $\mathrm{O}$ trabalho versificatório é precedido por imaginário "carteggio inedito" curioso e pitoresco entre mestre e discípulo...

Completam a bagagem literária do autor Prose e Rime extravaganti e Parlami d'amore, duas pequenas jóias de sua lavra.

Como jurista e romanista, porém, é que Gaetano Sciascia ficou mais conhecido na Itália e no Brasil. Suas Varietà Giuridiche Scritti brasiliani di Diritto Romano e Moderno (1956) contém importante estudo sobre "As relações entre o Brasil e a Itália no campo do Direito", começando pelo histórico da sequiência dos atos internacionais celebrados pelos dois Estados entre 1829 e o tratado de Versalhes; segue-se o inventário dos atos bilaterais vigentes antes de 21.8.1942. Feita a paz com a Itália em 1947, vêm entre outros o acordo assinado em 1949 para incentivar as relações de colaboração entre os dois países; o acordo sobre investimentos de capital italiano e participação de cidadãos italianos em empresas brasileiras (1950); o acordo de migração entre o Brasil e a Itália (1950). Segue-se uma análise sobre as condições da aplicação do Direito italiano no Brasil (Direito Internacional Privado). Termina o volume com um capítulo sobre as linhas da 
evolução do Direito Privado até as codificações, com precioso apanhado sobre as relações através dos séculos entre o Brasil e a Itália.

Basta considerar, mesmo sumariamente, o elenco dos assuntos tratados pela inteligência brilhante de Gaetano Sciascia para reconhecermos logo a importância imorredoura de sua contribuição no sentido do estreitamento das relações culturais ítalo-brasileiras.

São Paulo, fevereiro de 1996. 